
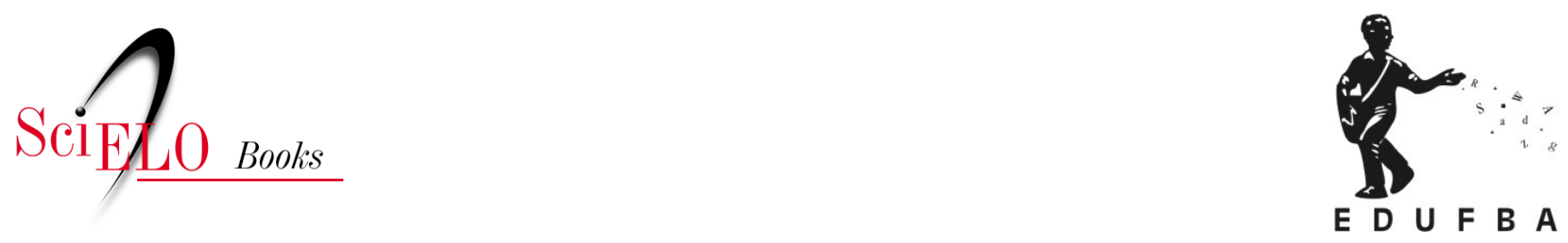

\title{
Reflexões \\ Um parque genial com skate, livros e games
}

\author{
Nelson De Luca Pretto
}

\section{SciELO Books / SciELO Livros / SciELO Libros}

PRETTO, N.D.L. Um parque genial com skate, livros e games. In: Educações, culturas e hackers: escritos e reflexões [online]. Salvador: EDUFBA, 2017, pp. 142-143. ISBN: 978-85-232-2019-8. https://doi.org/10.7476/9788523220198.0031.

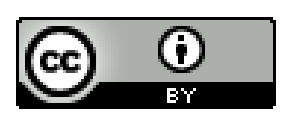

All the contents of this work, except where otherwise noted, is licensed under a Creative Commons Attribution $\underline{4.0 \text { International license. }}$

Todo o conteúdo deste trabalho, exceto quando houver ressalva, é publicado sob a licença Creative Commons Atribição 4.0. 
Além do cordel, muita música foi criada a partir do meteorito. Relembro, com muito carinho, do grupo baiano de mesmo nome liderado por Gereba, composto, entre outros, pelo mago do atual marketing político petista, João Santana Filho que, à época, era somente Patinhas, meu contemporâneo do Colégio Antônio Vieira, em Salvador.

Tenho um dos belos discos (LP) desse grupo, criado na década de 1970 do século passado. Procurei um pouco sobre eles na internet e, por conta disso, encontrei o projeto do Dicionário Cravo Alvin da Música Popular Brasileira ${ }^{32}$ que tem apoio da FIPEP e Faperj. Nele, um pouco da história do grupo. As composições do Bendegó eram de Gereba e Patinhas, mas também estavam presentes grandes nomes da música baiana como Zeca, Kapenga, Carlos Eládio, Tuzé de Abreu, Carlos Pita, Capinam e muitos outros. Bela é As muié santa de Canudos, composição de Gereba e Patinhas, mas no Youtube só achei Além de Arembepe, com uma divertida imagem da turma.

Ouça a música, assista aos vídeos e se prepare: outros meteoros e meteoritos virão e o mundo, por certo, não vai acabar por conta deles. Mas muita arte e ciência poderão ser produzidas.

\section{Um parque genial com skate, livros e games}

Dias atrás, estive em Passo Fundo, no Rio Grande do Sul. Cidade bem arrumada, com boa comida e um polo universitário que cresce a olhos

\footnotetext{
${ }^{32}<$ http://www.dicionariompb.com.br/bendego/dados-artisticos>. Acesso em: 10 maio 2017.
} 
vistos. A tradicional Universidade de Passo Fundo é uma das 250 universidades comunitárias existentes no país e uma referência na região.

Passo Fundo também ficou conhecido nacionalmente pelas sensacionais Jornadas Nacionais de Literatura, organizada sob a forte liderança da professora Tania Rösing.

Pois foi com ela que, dias atrás, visitei um enorme parque em construção, o Parque da Gare, com uma área de $50 \mathrm{mil} \mathrm{m}^{2}$, antes largada ao abandono e, hoje, sendo transformada num espaço público para a cidade, com uma variedade de equipamentos urbanos. Caminhava pelas obras ao lado das equipes da Prefeitura, ouvindo explicações da própria Tania, que me pedia uns pitacos no projeto.

A pista de skate, no alto, foi desenhada em conjunto com a meninada, pois para projetá-la precisavam saber mais detalhes do esporte. Um pouco abaixo, o teatro a céu aberto. Mais ao lado, as quadras de esporte, acima de um lago, fruto do represamento da água oriunda de algumas fontes da região. Chegamos à menina dos olhos da professora Tânia: o Prisma. Um prédio desenhado por um grupo espanhol em formato de prisma, projetado inicialmente para ser uma biblioteca. Aqui nossa conversa ficou mais interessante. A biblioteca do projeto passará a ser a Estação Cultural da Gare, com $664 \mathrm{~m}^{2}$ de edificação, abrigando, além dos livros impressos, um conjunto de objetos tecnológicos, digitais ou não, para estimular as juventudes nas leituras, ambas aqui escritas nesse plural pleno. Computador, tablet, videojogo, gamão, dama, xadrez, televisão, equipamentos múltiplos para leituras múltiplas. A formação plena das juventudes era o nosso foco.

Para fortalecê-las, é necessário oferecer-lhes generosos espaços públicos e isso é sempre um bom caminho para a construção de uma sociedade menos intolerante, coisa que precisamos muito nesse momento brasileiro. 